\title{
Contribution to the knowledge of rupicolous plant communities in the limestone areas of North Africa
}

\author{
A. M. RoMo \\ Botanical Institute of Barcelona (CSIC-ICUB), Passeig del Migdia s/n, Parc de Montjuïc, 08038 Barcelona, Spain. \\ E-mail: a.romo@ibb.csic.es
}

Received 2 November 2007; Accepted 7 December 2007

\begin{abstract}
The rupicolous plant communities of the Moroccan Rif and Atlas Mountains and the Algerian Djurjura Mountains have been studied in this contribution. The structure and floristic composition of these plant communities are described according to the phytosociological methodology. The following seven new syntaxa are described: Saxifrago tricrenatae-Poetum ligulatae and Saxifrago globuliferae-Seslerietum argenteae from the Western Rif; Drabo hispanicae-Pterocephaletum kunkeliani from the Eastern Rif; Saxifrago globuliferae-Geranietum cataractari from the Middle Atlas; Arabido alpinae-Festucetum atlanticae from the High Atlas; Centaureo benoistii-Galietum ephedroides from the Saharan Atlas and Poo alpinae-Saxifragetum numidicae from the Djurjura mountainous region.

New data referring to the chorology and floristic composition of the other previously described syntaxons are also provided.
\end{abstract}

Key words: rupicolous plant communities, Morocco (Atlas Mountains, Rif), Algeria (Djurjura), vegetation, phytosociology.

\section{INTRODUCTION}

The first global vision regarding the rupicolous communities of the Magreb was provided by QuÉZEL $(1952,1957)$. In these works, the major rupicolous formations of the high mountain vegetation of the Great Eastern, Central and Western Atlas, and the Middle Atlas, are described. More recently, and without going into excessive detail as regards the studies made, it is worth mentioning that DeIL (1994) studied the rupicolous communities present on both sides of the Straits of Gibraltar, DeIL \& HAMmoumi (1994) the Bokkoya Massif in the Eastern Rif, DeIL (1996) the rock seep communities in the whole of Morocco referable to the class Adiantetea, GÉHU \& BIONDI (1998) the maritime rupicolous communities with macaronesian affinities, MÉDAIL \& QuÉzel (1999) the rupicolous communities of the Anti-Atlas with Dracaena and DeIL (2006) has recently studied
Ptilostemon rock communities in the Central Rif Mountains. We must also remember that DeIL \& GALÁN DE MERA (1996) have elaborated a synthesis on the limestone plant communities in Morocco.

However, over extensive areas of mountainous terrain, such as the Western Rif or the Djurjura in the (Algerian) Kabylie, their study has, at best, been fragmentary. And the principal massifs of the Atlas also reveal an only partial knowledge of the middle altitude rupicolous vegetation, since the greater part of the botanical exploration of this range has been carried out at the high mountain level. The question, therefore, is whether or not the rupicolous plant communities are in fact well known.

While carrying out our field work, we explored in particular the mid-elevation mountain areas, and little-studied areas of the Rif, the Middle Atlas and the Djurjura, and to a lesser extent the Great Atlas and Anti-Atlas. 


\section{Materials AND MethodS}

Throughout the process of our botanical explorations of Morocco and Algeria, a number of relevés in accordance with the phytosociological methodology of Braun-BlanqueT (1977), MuELLERDumbois \& Ellenberg (1974) and DierschKe (1994) were elaborated. In these relevés the slope is given in degrees, not as percentage.

For the nomenclature of the plants we have referred to the works of VALDÉS et al. (2002) for Northern Morocco, FenNANE et al. (1999 and 2007) and JAHANDIEZ \& MAIRE (1931) for the rest of the country; and QUÉZEL \& SANTA (1962) for Algeria.

\section{RESULTS}

Numerous associations, hitherto not recognized, have been detected and are described in the following section.

\section{Saxifrago tricrenatae-Poetum ligulatae, assoc. nova}

This association (Table 1) is characterized by the presence of rupicoles (saxicoles) some of which are of a very restricted range: Saxifraga tricrenata is an endemic to the central-West Rif (MATEOS, 2003) and is a taxon (described by Font Quer in his Iter Maroccanum, 1928: 156, see GonZÁLEZ BUENO, 1988) which was ignored by VARGAS (2003); Arenaria grandiflora subsp. gomarica is endemic to the western Rif, known at present from the Jbels: Lexhaab or Lakraa, Tissouka, Tasnot and Arhoud, ROMO \& BORATYŃSKI (2007b) and SÁEz et al. (2002); Globularia liouvillei subsp. greuteri is an endemic plant of Jbel Lakraa, recently described by MATEOS \& VALDÉS (2006); and Potentilla caulescens subsp. achhalii is an endemic plant from the Middle Atlas and Rif mountains (Romo, 2003). All these taxa highlight the great richness of endemic species from these rupicolous communities of the Western Rif (Romo, 1995).

It colonizes the limestone cliffs of a supra-montane level, preferably with a northern or eastern orientation, at between 1600 and $2000 \mathrm{~m}$. It can be found in the domain of the Abies maroccana woodlands
(BENABID, 1982). It colonizes the areas which receive a head-on influence of the humid air masses from the Mediterranean sea, in zones of condensation and of a high precipitation (QUÉZEL, 2000).

In its well formed state, it can be found from Jbel Tissouka to Jbel Lakraa or Adrar Lexhab. It is fairly uniform throughout this area (Fig. 1).

This new association should be included in the Violon Saxifragae Quézel 1952 alliance.

As typus relevé of the association, number three of Table 1 has been taken.

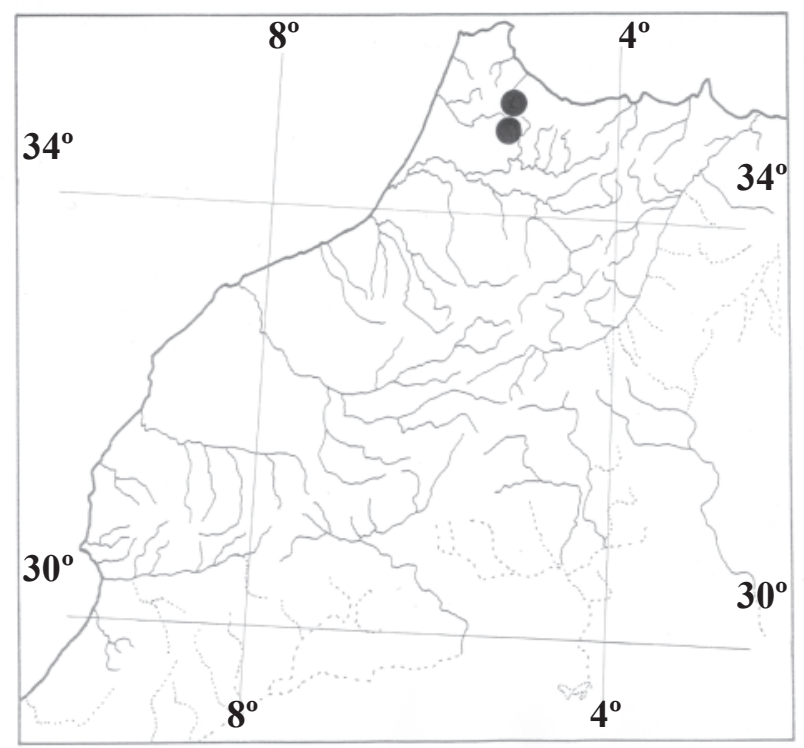

Figure 1. Distribution of Saxifrago tricrenataePoetum ligulatae.

\section{Saxifrago globuliferae-Seslerietum argenteae, assoc. nova}

Among the species characteristic of this association, the presence of the following mountain species (orophytes) should be mentioned: Erinus alpinus, Sesleria argentea subsp. gomarica and Festuca rifana (Table 2).

This association is typical of the limestone cliffs with a northern orientation, situated between 1400 and $1600 \mathrm{~m}$, and exceptionally to $1700 \mathrm{~m}$. As from this altitude, this community is substituted by the Saxifrago tricrenatae-Poetum ligulatae.

It occurs in the Quercus rotundifolia domain and in the areas where this domain meets the Abies maroccana domain. 
Table 1. Saxifrago tricrenatae-Poetum ligulatae. Origin of the relevés: 1-5 Morocco, Western Rif, above

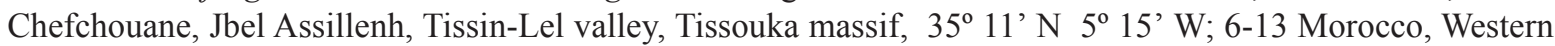
Rif, Jbel Lakraa or Adrar Lexhab, $35^{\circ} 09^{\prime} \mathrm{N} 5^{\circ} 08^{\prime} \mathrm{W}$.

\begin{tabular}{|c|c|c|c|c|c|c|c|c|c|c|c|c|c|}
\hline & \multicolumn{13}{|c|}{ Number of relevé } \\
\hline & 1 & 2 & 3 & 4 & 5 & 6 & 7 & 8 & 9 & 10 & 11 & 12 & 13 \\
\hline Aspect & $\mathrm{N}$ & $\mathrm{N}$ & $\mathrm{N}$ & $\mathrm{E}$ & $\mathrm{E}$ & $\mathrm{NE}$ & $\mathrm{W}$ & $\mathrm{NE}$ & $\mathrm{NE}$ & NW & $\mathrm{E}$ & $\mathrm{N}$ & $\mathrm{N}$ \\
\hline Slope & 90 & 90 & 90 & 90 & 90 & 90 & 90 & 90 & 90 & 90 & 90 & 90 & 90 \\
\hline Cover & 25 & 30 & 30 & 40 & 40 & 35 & 40 & 40 & 40 & 40 & 35 & 40 & 40 \\
\hline Altitude (x10) & 160 & 165 & 165 & 174 & 164 & 180 & 186 & 185 & 187 & 187 & 190 & 188 & 188 \\
\hline Studied surface $\left(\mathrm{m}^{2}\right)$ & 15 & 20 & 30 & 20 & 20 & 15 & 20 & 20 & 20 & 20 & 30 & 20 & 20 \\
\hline \multicolumn{14}{|c|}{ Characteristics of the association and of the superior units } \\
\hline Saxifraga tricrenata & 2.3 & 2.3 & 3.3 & 2.2 & 3.3 & . & 2.4 & 2.2 & 3.4 & 2.3 & . & 2.3 & 2.3 \\
\hline $\begin{array}{l}\text { Arenaria grandiflora } \\
\text { subsp. gomarica }\end{array}$ & 1.1 & . & . & . & . & + & 1.2 & 1.1 & . & 1.2 & . & 1.2 & 1.1 \\
\hline Erinus alpinus & . & 2.1 & 2.3 & + & . & 2.2 & . & 1.2 & . & 1.2 & 1.1 & . & . \\
\hline Asplenium ceterach & 1.1 & 1.1 & . & 1.1 & . & . & . & . & . & . & . & . & . \\
\hline Crepis albida & . & . & . & 1.1 & . & + & . & . & + & + & + & . & . \\
\hline $\begin{array}{l}\text { Centranthus nevadensis } \\
\text { subsp. nevadensis }\end{array}$ & . & . & . & 1.1 & . & . & . & . & . & . & 1.1 & . & . \\
\hline $\begin{array}{l}\text { Potentilla caulescens } \\
\text { subsp. achhalii }\end{array}$ & . & . & $\cdot$ & . & . & 2.3 & . & 1.2 & . & . & . & . & . \\
\hline Leontodon tingitanus & 1.1 & 1.1 & . & 1.1 & . & . & . & . & . & . & . & . & . \\
\hline Cystopteris fragilis & . & . & . & . & . & . & . & . & + & + & . & . & \\
\hline $\begin{array}{l}\text { Globularia liouvillei } \\
\text { subsp. greuteri }\end{array}$ & . & . & . & . & . & + & + & . & . & . & . & . & . \\
\hline Rhammus pumila & . & . & . & . & . & 1.2 & . & . & . & 2.3 & 1.3 & 1.2 & . \\
\hline $\begin{array}{l}\text { Draba hispanica } \\
\text { subsp. hispanica }\end{array}$ & $\cdot$ & . & . & . & . & 1.1 & . & . & . & + & 1.1 & . & . \\
\hline $\begin{array}{l}\text { Asplenium trichomanes } \\
\text { subsp. quadrivalens }\end{array}$ & . & . & $\cdot$ & 1.1 & . & - & . & . & . & . & . & . & . \\
\hline Silene andryalifolia & 1.1 & . & 2.2 & $\cdot$ & . & . & . & . & . & . & . & . & . \\
\hline Sedum dasyphyllum & 1.1 & + & + & 1.1 & . & . & . & . & . & . & . & . & . \\
\hline $\begin{array}{l}\text { Sedum mucizonia } \\
\text { subsp. mucizonia }\end{array}$ & + & . & + & + & . & - & . & . & . & . & . & . & . \\
\hline $\begin{array}{l}\text { Chaenorhinum villosum } \\
\text { subsp. granatense }\end{array}$ & . & . & 1.1 & + & + & . & . & . & . & . & . & . & . \\
\hline Prunus prostrata & . & . & . & . & . & . & . & . & + & . & . & . & . \\
\hline Linaria tristis subsp. pectinata & . & . & . & . & + & + & . & + & . & . & . & . & . \\
\hline
\end{tabular}


Table 1. Cont.

\begin{tabular}{|c|c|c|c|c|c|c|c|c|c|c|c|c|c|}
\hline \multirow[b]{3}{*}{ Arabis alpina } & \multicolumn{12}{|c|}{ Number of relevé } & \multirow[b]{2}{*}{13} \\
\hline & 1 & 2 & 3 & 4 & 5 & 6 & 7 & 8 & 9 & 10 & 11 & 12 & \\
\hline & 1.1 & . & . & . & . & . & . & . & . & . & . & . & $\cdot$ \\
\hline Cerastium gibraltaricum & . & . & . & + & . & . & . & . & . & . & . & . & . \\
\hline \multicolumn{14}{|l|}{ Acompanying taxa } \\
\hline Poa ligulata subsp. paui & 2.2 & 2.2 & 2.1 & 2.2 & . & . & . & 1.1 & . & . & . & . & 1.1 \\
\hline $\begin{array}{l}\text { Avenula gervasii } \\
\text { subsp. arundana }\end{array}$ & + & 1.1 & . & . & . & . & . & . & . & . & . & . & 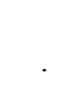 \\
\hline Festuca hystrix & . & . & . & . & . & + & . & +.2 & . & . & . & + & . \\
\hline Pimpinella villosa & . & . & . & . & . & . & . & . & . & . & + & + & 1.1 \\
\hline Sanguisorba rupicola & . & + & + & . & . & . & . & . & . & . & . & . & . \\
\hline Galium album & . & . & + & . & + & . & . & . & . & . & . & . & . \\
\hline $\begin{array}{l}\text { Scabiosa turolensis } \\
\text { subsp. maroccana }\end{array}$ & . & . & . & . & . & . & . & . & + & + & . & . & $\cdot$ \\
\hline Minuartia hybrida & . & + & . & . & . & . & . & . & . & . & . & . & $\cdot$ \\
\hline Taraxacum obovatum & . & . & + & . & . & . & . & . & . & . & . & . & . \\
\hline Alyssum serpyllifolium & . & . & + & . & . & . & . & . & . & . & . & + & . \\
\hline Alysssum spinosum & . & . & . & . & . & . & . & . & . & . & . & + & . \\
\hline Carex hallerana & . & . & + & . & . & . & . & . & . & . & . & . & 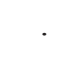 \\
\hline Asperula laevigata & . & . & + & . & . & . & . & . & . & . & . & . & . \\
\hline Berberis hispanica & . & . & . & . & . & . & . & . & . & . & . & . & +.2 \\
\hline $\begin{array}{l}\text { Dianthus sylvestris } \\
\text { subsp. longicaulis }\end{array}$ & . & . & . & . & . & 2.2 & . & . & . & . & . & . & \\
\hline Eryngium mohamedanii & . & . & . & . & . & + & . & . & . & . & . & . & \\
\hline Ononis aragonensis & . & . & . & . & . & . & + & . & . & . & . & . & \\
\hline Iberis grosmiquelii & . & . & . & . & . & . & . & . & . & . & . & + & \\
\hline
\end{tabular}

It colonizes the montane limestone cliffs of the Western Rif, where it occurs from the Jbel Lakraa in the east to Jbel Tissouka, further west (Fig. 2).

Owing to its floristic composition, it should be referred to the Violon saxifragae Quézel 1952 alliance. Despite being species-poor, it contains numerous endemics such as Sesleria argentea subsp. gomarica, a taxon found in a limited area of the limestone mountains of the Ghomara and the neighbourhood of Xauen (Romo, 1987) and which, surprisingly, does not appear in ROMEROZARCO (2002). Apart from Sesleria argentea subsp. gomarica, Erinus alpinus and Festuca fontqueri are also lacking in areas of higher elevation. 
Table 2. Saxifrago globuliferae-Seslerietum argenteae. Origin of the relevés: Morocco, West-

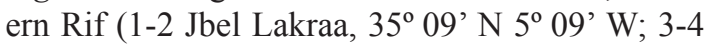
Jbel Tissouka, Sfiha Telj, $\left.35^{\circ} 10^{\prime} \mathrm{N} 5^{\circ} 13^{\prime} \mathrm{W}\right)$.

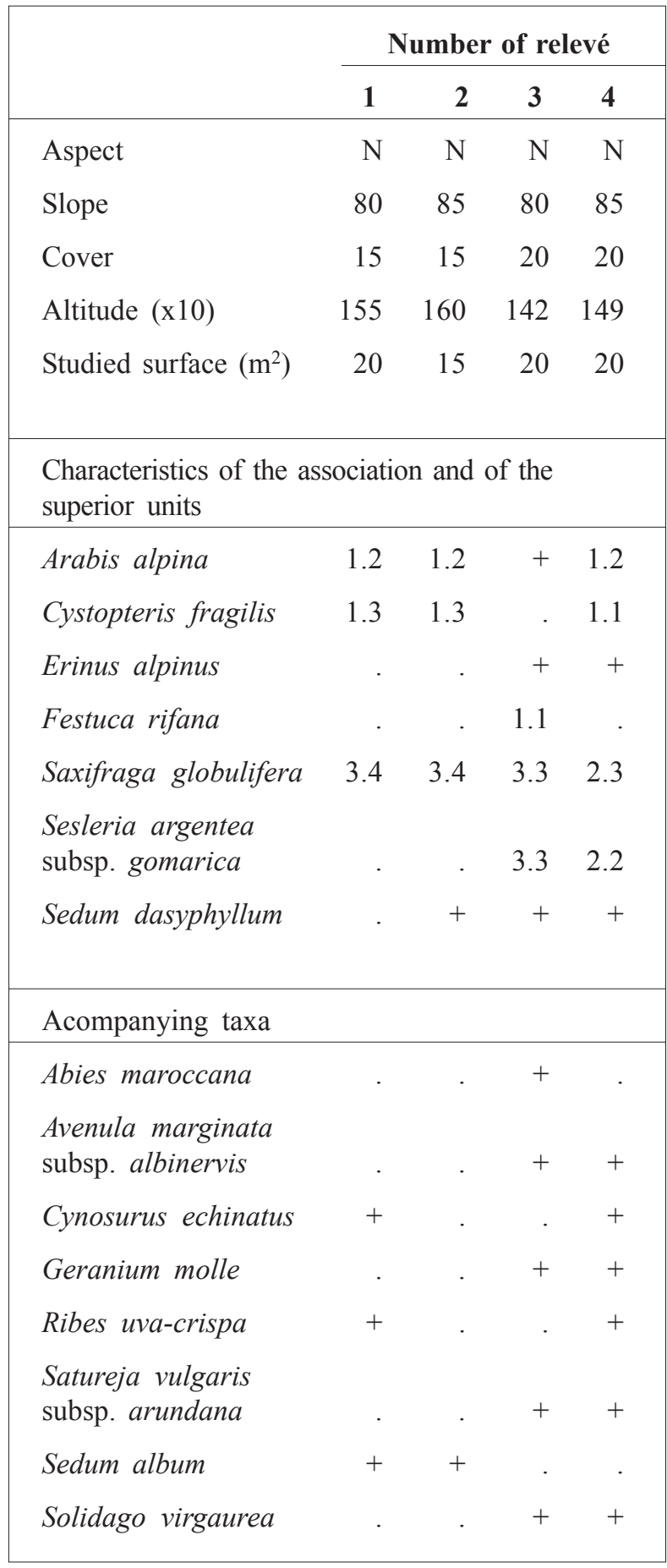

Number 3 of Table 2 has been taken as a typus relevé.

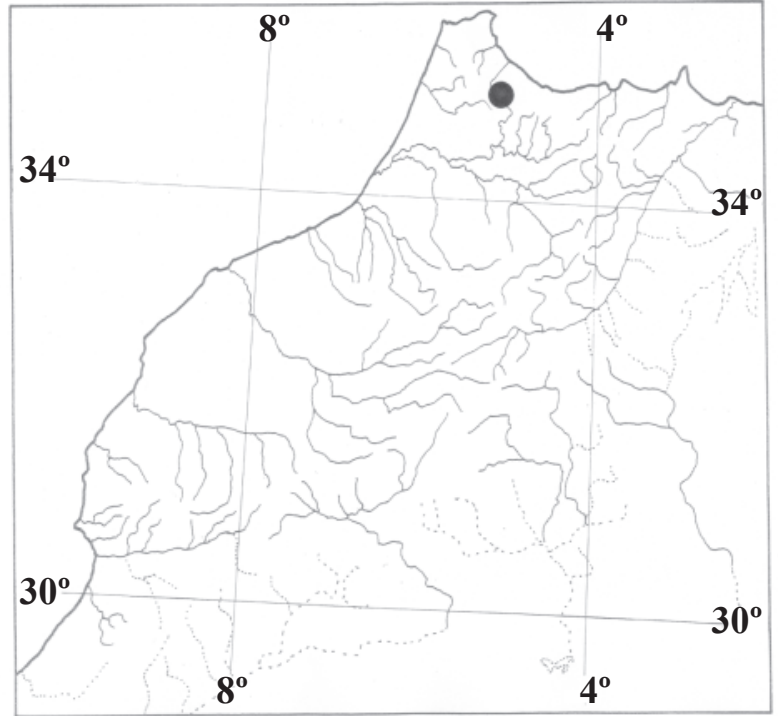

Figure 2. Distribution of Saxifrago globuliferaeSeslerietum argenteae.

\section{Drabo hispanicae-Pterocephaletum kunkeliani, assoc. nova}

Among the species characteristic of this association (Table 3), apart from some significant endemics such as Pterocephalus kunkelianus, an eastern Rif endemic, vicariant of Pterocephalus depressus, a species widespread in the High Atlas, Romo et al. (1999), the following species stand out: Silene patula subsp. patula and Draba hispanica subsp. hispanica. Other taxa which reach the eastern limit of their range in the Rif include: Paronychia maroccana, Erinus alpinus and Arenaria armerina.

This association is typical of the shaded limestone cliffs, with a northern orientation. It occurs in the higher montane level, falling within the limits of the oromediterranean zone, from 1800 to $1980 \mathrm{~m}$, in the domain of Quercus rotundifolia woodlands.

It colonizes the limestone cliffs of the Azrou Akechar massif. This massif is one of the highest in the Eastern Rif and is isolated from the other massifs of a similar elevation. Apart from its solitary aspect, the presence of calcareous substrates in an area where this type of substrate is rare should be noted. The great calcareous massifs are to be found in the Western Rif, whereas the Central and Eastern Rif are dominated by siliceous rocks (Fig. 3). 
Table 3. Drabo hispanicae-Pterocephaletum kunkeliani. Origin of the relevés: 1-4 Morocco, Eastern Rif, Jbel Azrou Akechar, above Tizi Ousli, $34^{\circ} 47^{\prime} \mathrm{N} 3^{\circ} 51^{\prime} \mathrm{W}$.

\begin{tabular}{|c|c|c|c|c|}
\hline & \multicolumn{4}{|c|}{ Number of relevé } \\
\hline & 1 & 2 & 3 & 4 \\
\hline Aspect & $\mathrm{N}$ & $\mathrm{N}$ & $\mathrm{N}$ & $\mathrm{N}$ \\
\hline Slope & 90 & 90 & 90 & 90 \\
\hline Cover & 40 & 45 & 40 & 40 \\
\hline Altitude (x10) & 195 & 194 & 194 & 193 \\
\hline Studied surface $\left(\mathrm{m}^{2}\right)$ & 20 & 20 & 20 & 20 \\
\hline \multicolumn{5}{|c|}{$\begin{array}{l}\text { Characteristics of the association and of the } \\
\text { superior units }\end{array}$} \\
\hline Saxifraga globulifera & 1.2 & 1.2 & 2.3 & 1.2 \\
\hline $\begin{array}{l}\text { Pterocephalus } \\
\text { kunkelianus }\end{array}$ & 2.2 & 2.3 & 1.2 & 2.2 \\
\hline $\begin{array}{l}\text { Silene patula } \\
\text { subsp. patula }\end{array}$ & 2.3 & 2.3 & 1.2 & 2.3 \\
\hline $\begin{array}{l}\text { Draba hispanica } \\
\text { subsp. hispanica }\end{array}$ & + & 1.1 & + & + \\
\hline Arenaria armerina & . & 1.2 & 1.1 & 1.1 \\
\hline Paronychia maroccana & . & + & + & + \\
\hline Crepis albida & . & + & + & + \\
\hline Erinus alpinus & 1.1 & . & . & + \\
\hline Hypochoeris laevigata & . & + & + & + \\
\hline \multicolumn{5}{|l|}{ Acompanying taxa } \\
\hline Asperula aristata & + & + & 1.1 & . \\
\hline Dianthus brachyanthus & + & + & . & + \\
\hline Leontodon eriopodus & + & + & . & + \\
\hline Biscutella atlantica & + & . & + & + \\
\hline Chrysanthemum demnaten & ase + & + & . & . \\
\hline
\end{tabular}

This new syntaxon, in spite of its being poor in species, should be included in the Violon saxifragae Quézel 1952 alliance.

As a typus relevé, number 1 of Table 3 has been taken.

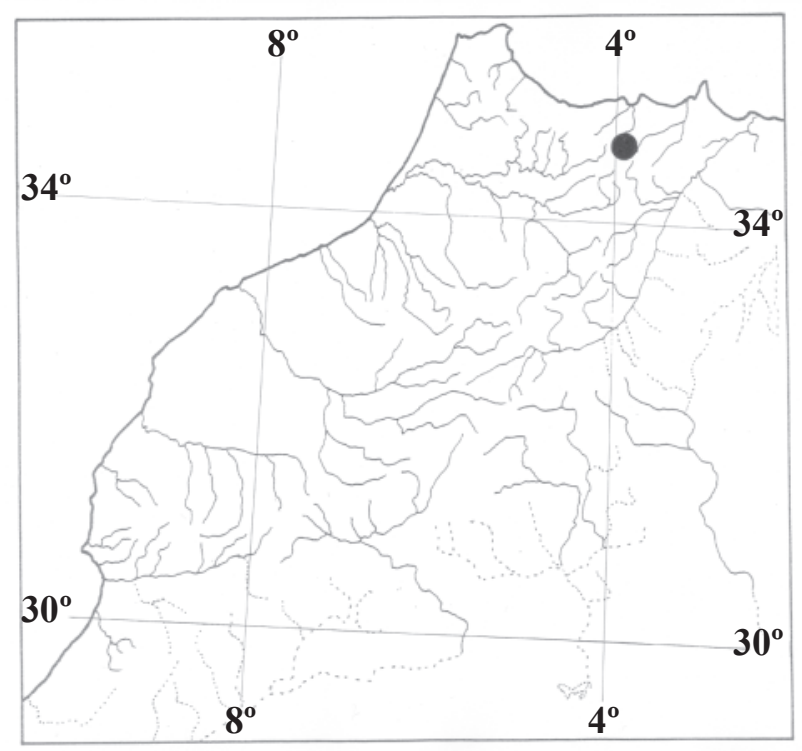

Figure 3. Distribution of Drabo hispanicaePterocephaletum kunkeliani.

\section{Saxifrago globuliferae-Geranietum cataractari, assoc. nova}

This association (Table 4) is characterized by the presence of, among other species, the following rupicoles: Saxifraga globulifera var. spathulata, Biscutella frutescens, Silene patula subsp. patula, Sarcocapnos crassifolia, Draba hispanica and Linaria tristis subsp. marginata.

Geranium cataractanum subsp. pitardii is an endemic rupicoulous plant from limestone cliffs of the Middle Atlas, which has also been reported from the High Atlas, Jbel Ayachi at $3100 \mathrm{~m}$, by Guittonneau (1975). However, as FonT QueR (1931) stated, the characters on which the subspecies is based are variable, such that the recognition of this endemic entity requires further study.

It colonizes the limestone cliffs with a northern orientation, from between (1500) 1600 and $2000 \mathrm{~m}$. It is found in the domain of Cedrus atlantica woodland and in the limits of the Quercus rotundifolia woodlands domain where this meets the Cedrus atlantica domain.

It colonizes the areas which receive a direct influence from the humid Atlantic winds. It is to be found in zones of high rainfall and atmospheric condensation.

This association grows on montane zones of the Middle Atlas, where it is known from Jbel Hebri 
Table 4. Saxifrago globuliferae-Geranietum cataractari. Origin of the relevés: 1-10 Morocco, Middle Atlas, towards Azrou, consolidated limestones close to Timahdite, $98 \mathrm{~km}$ to the south of Meknès, between 18201860 m., $36^{\circ} 93^{\prime} \mathrm{N} 8^{\circ} 22^{\prime}$ W; 11-15 Morocco, Middle Atlas, Jbel Tazzeka, cliffs of Bab Bou Idir, to Bab BouIdir, $34^{\circ} 02^{\prime} \mathrm{N} 4^{\circ} 08^{\prime} \mathrm{W}$.

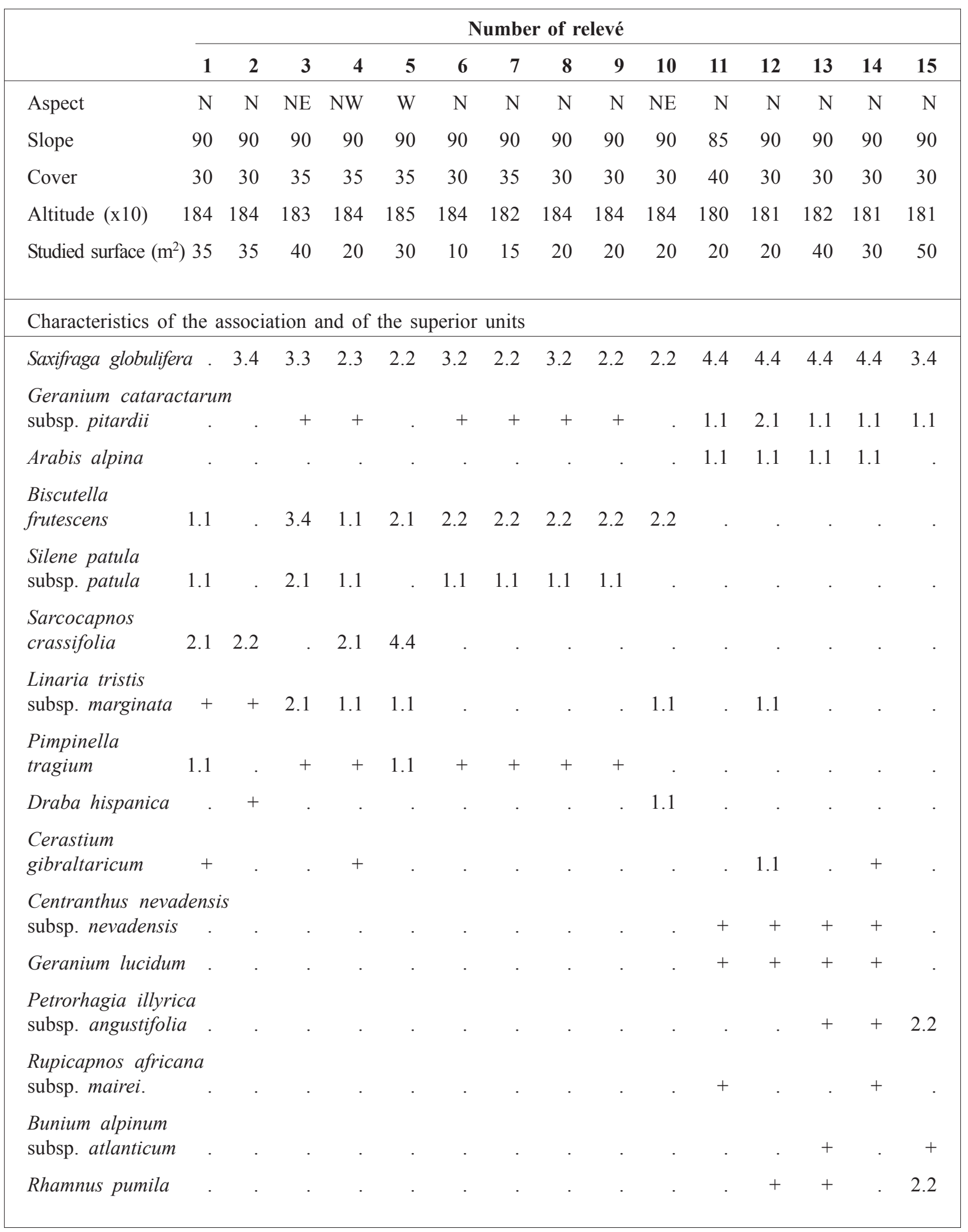


Table 4. Cont.

\begin{tabular}{|c|c|c|c|c|c|c|c|c|c|c|c|c|c|c|c|}
\hline \multicolumn{16}{|c|}{ Number of relevé } \\
\hline & 1 & 2 & 3 & 4 & 5 & 6 & 7 & 8 & 9 & 10 & 11 & 12 & 13 & 14 & 15 \\
\hline Crepis albida & . & . & . & . & . & . & . & . & . & . & . & + & . & + & . \\
\hline $\begin{array}{l}\text { Pritzelago alpina } \\
\text { subsp. font-queri }\end{array}$ & . & . & . & . & . & . & . & . & . & . & . & + & . & . & . \\
\hline $\begin{array}{l}\text { Chaenorrhinum } \\
\text { villosum } \\
\text { subsp. granatense } 1 .\end{array}$ & 1.1 & + & . & . & . & . & . & . & . & . & . & . & . & . & . \\
\hline Prunus prostrata & . & . & . & . & . & . & . & . & . & . & . & . & . & + & . \\
\hline \multicolumn{16}{|l|}{ Acompanying taxa } \\
\hline Galium mollugo 1. & 1.1 & + & . & . & 1.1 & 1.1 & 1.1 & 1.1 & 1.1 & 1.1 & . & . & . & . & . \\
\hline Sanguisorba rupicola & . & . & 1.1 & . & . & . & + & . & . & . & . & . & . & . & . \\
\hline Ribes uva-crispa & + & . & . & . & + & . & . & . & . & . & . & . & . & . & . \\
\hline $\begin{array}{l}\text { Dactylis glomearta } \\
\text { subsp. hispanica }\end{array}$ & . & . & . & . & . & + & + & + & + & . & . & . & . & . & . \\
\hline Bupleurum spinosum & + & . & + & . & . & . & . & . & . & . & . & . & . & . & . \\
\hline $\begin{array}{l}\text { Rhamnus lycioides } \\
\text { subsp. velutina }\end{array}$ & . & + & . & . & 1.1 & . & . & . & . & . & . & . & . & . & . \\
\hline Plantago mauritanica & t. & . & . & . & . & . & . & . & + & + & . & . & . & . & . \\
\hline Umbilicus gaditanus & . & . & . & . & . & . & . & . & . & . & + & + & + & + & . \\
\hline Poa ligulata & . & . & . & . & . & . & . & . & . & . & . & + & + & . & 2.1 \\
\hline Cynosurus elegans & . & + & . & . & . & . & . & . & . & . & . & + & + & . & . \\
\hline
\end{tabular}

Species present in a single relevé: Chrysanthemum demnatense (+, 1); Cynosurus elegans (+, 2); Thymelaea virgata $(+, 3)$; Satureja alpina subsp. meridionalis $(+, 3)$; Sinapis incana $(+, 4)$; Sisymbrium orientale $(+, 4)$; Alyssum montanum s.l. (+, 4); Thymus zygis (+, 7); Euphorbia characias $(+, 7) ;$ Microlonchus duriaei $(+, 7)$; Teucrium polium s.1. (+, 7); Poa bulbosa (+, 8); Moehringia pentandra (2.2, 11); Lamium flexuosum (1.1, 11); Alyssum serpyllifolium (+, 11); Anthemis pedunculata subsp. pedunculata $(+, 11)$; Stachys circinata $(+, 11)$; Bromus benekenii $(+, 11)$; Tamus communis $(+, 11)$; Galium lucidum $(+, 12)$; Ferula communis $(+$, 12); Festuca ovina s.1. (+, 14); Silene colorata (+, 15); Hieracium cf. pseudopilosella (+, 15); Scandix australis $(+, 15)$.

and Jbel Tazzeka to the North, to Jbel Irhoud, further South (Fig. 4). In the latter massif, this being a more meridional locality, the species diversity grows poorer.

This new association should be included in the Coeno-Sarcocapnion Deil \& Galán de Mera 1996 alliance.

In the Jbel Ayachi, it is substituted by Biscutelletum frutescentis ayachicum Quézel (1953), typical of the shaded cliffs with a northern orientation, and situated between 2300 and $3200 \mathrm{~m}$ in the high mountain area of Jbel Ayachi in the Great Eastern Atlas. These are floristically very different, and in our association all the high mountain Mediterranean plants are lacking and, instead, numerous species of the middle mountain level can be found.

As a typus relevé of this association, number 3 of the Table 4 has been taken. 
QuÉzel (1957) described a close association: Pitardietum caerulescentis, from the Bou Naceur massif, characteristic of the zones of higher elevation of this Middle Atlas massif, where it is found in the limestone cliffs from 1800 to $2300 \mathrm{~m}$. In contrast, this new association occurs at a lower altitude, where high mountain Mediterranean plants are lacking, and where other species which are indicative of a higher degree of oceanic influence than occurs in Bou Naceur massif are present.

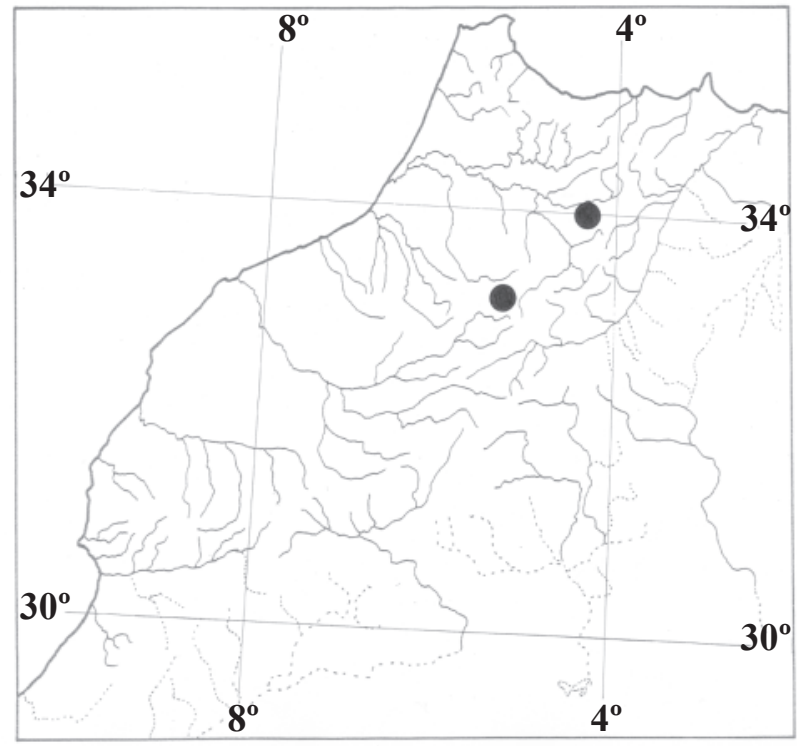

Figure 4. Distribution of Saxifrago globuliferaeGeranietum cataractari.

\section{Anthyllidetum warnieri, Quézel 1952}

Despite the limited number of species characteristic of this association (Table 5), these are plants of a very reduced distribution. Among them the following species stand out: Campanula schotteri, Aliella iminouakense and Carum iminouakense, all of these being taxa known at present only from the Imi-n-Ouakka gorge and its surroundings.

This association is typical of the fissures and ledges of the limestone cliffs with a northern orientation, from between 1700 and $1900 \mathrm{~m}$, these being somewhat ruderalized by the nitrogen-enriched droppings of the birds that colonize the rocks. It is found in the dominion of Juniperus thurifera subsp. africana woodlands (ROMO \& BORATYŃSKI, 2005, 2007a).

It colonizes the cliffs of limestone rocks at the middle-mountain level of the Great Central Atlas, where to date it is known only from the Imi-nOuaka Gorges (Fig. 5).

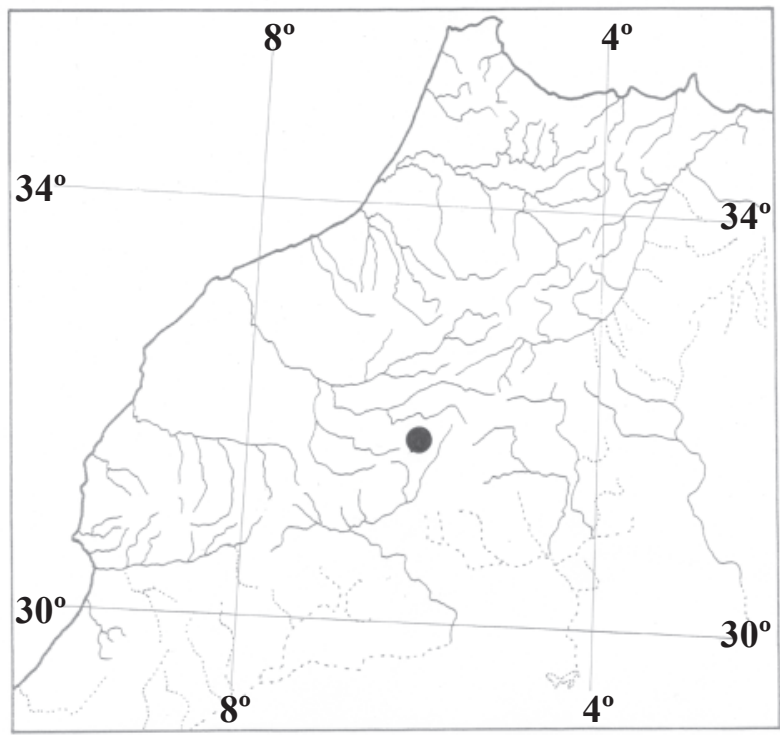

Figure 5. Distribution of Anthyllidetum warnieri.

Arabido alpinae-Festucetum atlanticae, assoc. nova

This association (Table 6) is characterized by the presence of, among other species, the following rupicoles: Aliella helichrysoides, Aliella platyphylla and Festuca atlantica.

Two distinct variants can be recognised.

The variant with Aliella platyphylla colonizes the porphyric cliffs with a northern orientation, from between 2600 and $3100 \mathrm{~m}$. It is found at the oromediterranean level, where it covers the areas which receive a direct influence from the humid Atlantic winds, in zones of high mountain conditions.

In contrast the southern facing cliffs, cracks, fissures and skeletal soils of the rock outcrops on granite rocks, from 2600 to $3100 \mathrm{~m}$, are dominated by the variant of Aliella helichrysoides.

This association grows on high altitude zones of the High Atlas, where it is known from Ousdim and Plateau de Tichka to the west to Jbel Angour and Oukaïmeden, further east (Fig. 6). 
Table 5. Anthyllidetum warnieri. Origin of the relevés: 1-7 Morocco, High Atlas, Imi-n-Ouaka Gorges, between Jbel Azegza and Jbel Alimane, 1800-1860 m, 31 37 $37^{\prime} \mathrm{N} 6^{\circ} 44^{\prime} \mathrm{W}$.

\begin{tabular}{|c|c|c|c|c|c|c|c|}
\hline \multirow[b]{3}{*}{ Aspect } & \multicolumn{6}{|c|}{ Number of relevé } & \multirow[b]{2}{*}{7} \\
\hline & 1 & 2 & 3 & 4 & 5 & 6 & \\
\hline & $\mathrm{S}$ & $\mathrm{N}$ & $\mathrm{N}$ & $\mathrm{NE}$ & NW & $\mathrm{N}$ & $\mathrm{N}$ \\
\hline Slope & 80 & 85 & 70 & 80 & 90 & 90 & 90 \\
\hline Cover & 15 & 20 & 15 & 15 & 30 & 20 & 20 \\
\hline Altitude (x10) & 182 & 182 & 186 & 182 & 184 & 184 & 180 \\
\hline Studied surface $\left(\mathrm{m}^{2}\right)$ & 10 & 15 & 12 & 15 & 12 & 12 & 15 \\
\hline \multicolumn{8}{|c|}{ Characteristics of the association and of the superior units } \\
\hline Campanula schotteri & $\cdot$ & 1.2 & . & + & . & 1.2 & 1.1 \\
\hline Aliella iminouakense & 1.1 & 2.3 & 1.1 & . & 1.1 & 2.2 & 1.2 \\
\hline Globularia nainii & 2.3 & . & 2.2 & 1.2 & 1.1 & 2.2 & . \\
\hline Polygala rupestris & . & . & 1.1 & . & . & 1.2 & . \\
\hline Anthyllis warnieri & . & 1.2 & 1.1 & . & 1.2 & . & 1.1 \\
\hline Asperula aristata & . & . & . & . & . & . & 2.2 \\
\hline Festuca ovina s. $l$. & . & 1.1 & 1.1 & + & + & . & + \\
\hline Saxifraga globulifera & . & . & . & . & . & . & + \\
\hline Fumana ericoides subsp. montana & $a$. & 1.1 & . & . & 1.1 & . & . \\
\hline Sedum dasyphyllum & . & . & . & . & + & + & . \\
\hline Putoria brevifolia & 1.2 & . & . & . & . & . & . \\
\hline Carum iminouakense & 1.1 & . & . & . & . & . & . \\
\hline Hieracium amplexicaule & . & . & . & 1.1 & . & + & . \\
\hline Centranthus battandieri & . & + & . & 1.1 & . & . & . \\
\hline \multicolumn{8}{|l|}{ Acompanying taxa } \\
\hline Anarrhinum fruticosum & . & . & . & + & . & . & . \\
\hline Galium ephedroides & . & 1.1 & 1.1 & . & . & . & . \\
\hline $\begin{array}{l}\text { Paronychia kapela } \\
\text { subsp. serpyllifolia }\end{array}$ & . & . & . & + & . & . & . \\
\hline Ephedra nebrodensis & . & . & . & . & . & + & . \\
\hline Bupleurum spinosum & . & . & . & . & . & + & . \\
\hline $\begin{array}{l}\text { Pimpinella tragium } \\
\text { subsp. litophila }\end{array}$ & - & $\cdot$ & . & + & . & . & . \\
\hline Bromus tectorum & . & . & + & . & . & . & . \\
\hline
\end{tabular}


Table 6. Arabido alpinae-Festucetum atlanticae. Origin of the relevés: 1-3 Morocco, Jbel Oukaïmeden, $31^{\circ} 11^{\prime} \mathrm{N} 7^{\circ} 52^{\prime} \mathrm{W}$; 4-6: Morocco, Jbel Angour, 31 ${ }^{\circ} 12^{\prime} \mathrm{N} 7^{\circ} 50^{\prime} \mathrm{W}$.

\begin{tabular}{|c|c|c|c|c|c|c|}
\hline & \multicolumn{6}{|c|}{ Number of relevé } \\
\hline & 1 & 2 & 3 & 4 & 5 & 6 \\
\hline Aspect & S & S & $\mathrm{S}$ & $\mathrm{NE}$ & $\mathrm{N}$ & $\mathrm{NE}$ \\
\hline Slope & 90 & 90 & 90 & 90 & 80 & 85 \\
\hline Cover & 15 & 20 & 15 & 30 & 20 & 15 \\
\hline Altitude (x10) & 295 & 298 & 300 & 300 & 299 & 300 \\
\hline Studied surface $\left(\mathrm{m}^{2}\right)$ & 10 & 10 & 10 & 15 & 12 & 10 \\
\hline \multicolumn{7}{|c|}{ Characteristics of the association and of the superior units } \\
\hline Aliella helichrysoides & 1.2 & 2.2 & 1.2 & . & . & . \\
\hline Aliella platyphylla & . & . & . & 2.2 & 1.2 & + \\
\hline Arenaria pungens & 1.1 & 2.2 & 1.2 & . & . & . \\
\hline Festuca atlantica & + & 1.1 & + & 1.1 & . & . \\
\hline Arabis alpina & + & . & . & 1.1 & 1.2 & . \\
\hline Festuca dyris & 1.1 & . & . & $\cdot$ & . & . \\
\hline Minuartia stereoneura & . & + & 2.1 & $\cdot$ & . & . \\
\hline Herniaria regnieri & . & . & . & . & . & + \\
\hline Hieracium amplexicaule & . & . & . & . & + & . \\
\hline Draba hispanica & . & . & . & . & . & + \\
\hline \multicolumn{7}{|l|}{ Acompanying taxa } \\
\hline Erinacea anthyllis & . & + & . & . & . & . \\
\hline Sideritis incana & . & . & 1.1 & . & . & . \\
\hline Bellis caerulescens & . & . & . & 2.1 & + & . \\
\hline
\end{tabular}

It colonizes the granite and porphyr cliffs of the high level of the High Atlas, and to date it is known only from localities ranging from the Oukaïmeden massif to the Jbel Ousdim.

QUÉZEL (1957) described a close association: Saxifrago maireanae-Phagnaletum platyphyllae, from the Toubkal, Bou-Ourioul and Tazerhart massifs, characteristic of the zones of lower elevation of this High Atlas area, where it is found in the sandy and schistic cliffs from 1900 to $2600 \mathrm{~m}$. In contrast, this new association occurs at a higher altitude, where Mediterranean mountain plants are lacking.

It should be included in the Violon saxifragae Quézel 1957 alliance.

Number 1 of the Table 6 has been taken as a typus relevé. 


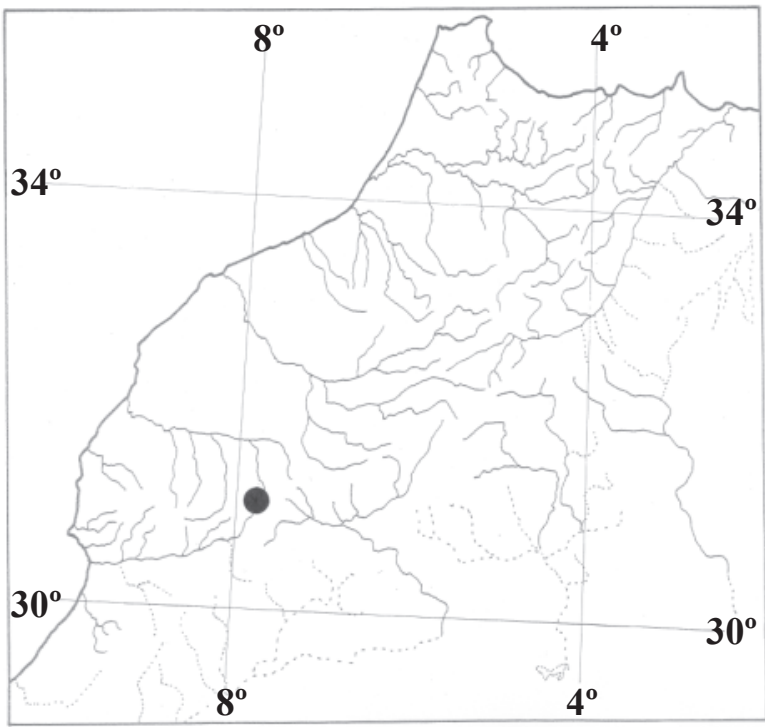

Figure 6. Distribution of Arabido-Festucetum atlanticae.

Centaureo benoistii-Galietum ephedroidis, assoc. nova

Among the species characteristic of this association (Table 7), the following are worthy of special mention: Centaurea benoistii, Galium ephedroides and Rhamnus atlantica.

This association is typical of the limestone cliffs with a western or northern orientation, from 1300 to $1600 \mathrm{~m}$. It is found in the dominion of Adenocarpo bacqueri-Buxetum (QUÉZEL \& BARBERO, 1981), scrublands, see BARBERO et al. (1981). It colonizes the very continental areas which are subject to strong thermal oscillations and reduced rainfall.

It colonizes the limestone cliffs of the montane level of the Great Saharan Atlas, and extends from the Jbel Tazigzaout in the north to the Jbel Izouggarn, situated further south (Fig. 7).

This new association should be included within the alliance: Bupleuro aiouensis-Globularion nainii Quézel, Barbero, Benabid, Loisel \& Rivas-Martínez, 1992.

As a typus relevé, number 2 of Table 7 has been taken.

According to QuÉzEL et al. (1994) it is replaced further south by Lavandulo brevidens-Hertietum maroccanae, between 1500 and $1600 \mathrm{~m}$; which in turn and at a lower altitude (between 1200 and
$1440 \mathrm{~m}$ ), is replaced by Convolvulo trabutianiGenistetum capitellatae.

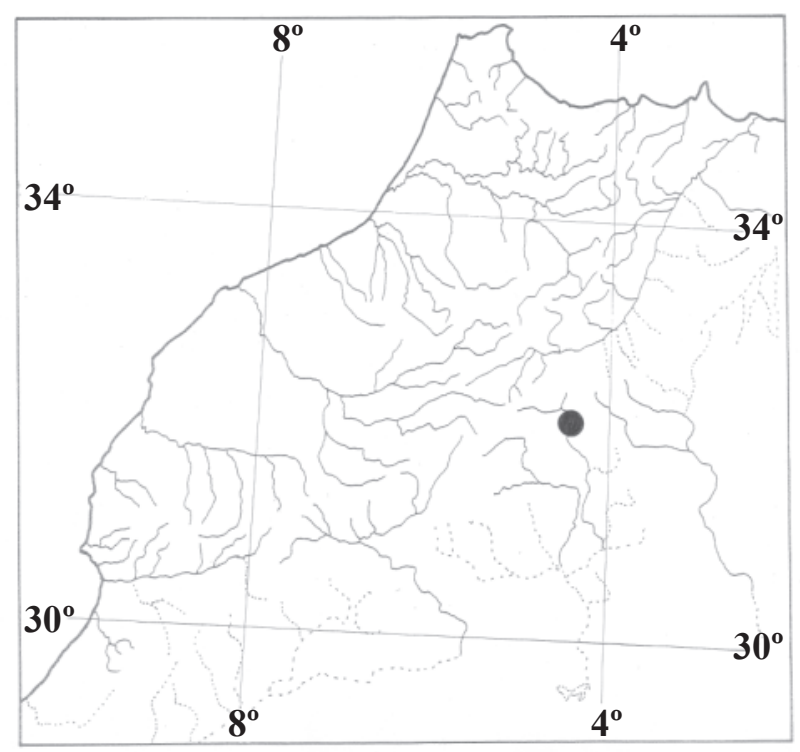

Figure 7. Distribution of Centaureo benoistiiGalietum ephedroides.

\section{Poo alpinae-Saxifragetum numidicae, assoc. nova}

Among the characteristic species of this association (Table 8) it is worth mentioning the presence of numerous endemics typical of the Djurjura massif: Saxifraga numidica, Leontodon djurjurae, and Poa alpina subsp. numidica.

This association is typical of the shaded limestone cliffs, with a northern orientation, from 1400 to $1700 \mathrm{~m}$. It is found in the domain of Quercus rotundifolia woodlands.

It colonizes the montane limestones cliffs of the Djurjura massif, to the east of Algeria, and to date it is known only from the Jbel Heidzer.

The Galio-Campanuletum jusiuriensis has been described by Quézel, which substitutes this association higher up, from 1700 to $2300 \mathrm{~m}$, WOJTERSKI (1985). This association has been included by QuÉzEL (1957: 103) into the Potentillion caulescentis alliance of the southern European mountains. To this same alliance the newly described association should be referred. This new syntaxon, despite been poorer in species, nontheless contains numerous endemics which are lacking in areas of greater elevation.

As a typus relevé, number 5 of the Table 8 has been taken. 
Table 7. Centaureo benoistii-Galietum ephedroidis. Origin of the relevés: 1-4 Morocco, Great Saharan Atlas, Gorges du Ziz, below Ait Serhouchène, towards Rich, crystalline limestones, 1590-1620 m, 32 $16^{\circ} \mathrm{N} \mathrm{5} 31^{\prime} \mathrm{W}$.

\begin{tabular}{|c|c|c|c|c|}
\hline & \multicolumn{4}{|c|}{ Number of relevé } \\
\hline & 1 & 2 & 3 & 4 \\
\hline Aspect & $\mathrm{N}$ & $\mathrm{W}$ & $\mathrm{W}$ & $\mathrm{N}$ \\
\hline Slope & 90 & 90 & 100 & 90 \\
\hline Cover & 20 & 30 & 25 & 30 \\
\hline Altitude (x10) & 159 & 160 & 162 & 160 \\
\hline Surface studied $\left(\mathrm{m}^{2}\right)$ & 30 & 20 & 30 & 40 \\
\hline \multicolumn{5}{|c|}{$\begin{array}{l}\text { Characteristics of the association and of the } \\
\text { superior units }\end{array}$} \\
\hline Galium ephedroides & 2.3 & 1.1 & 1.1 & 2.1 \\
\hline Centaurea benoistii & 1.1 & 1.1 & 2.1 & 1.1 \\
\hline Rhamnus atlantica & + & + & 1.1 & . \\
\hline $\begin{array}{l}\text { Anarrhinum } \\
\text { fruticosum (terr.) }\end{array}$ & . & $\cdot$ & $\cdot$ & + \\
\hline Delphinium balansae & . & . & . & + \\
\hline Lavandula tenuisecta & . & . & . & + \\
\hline \multicolumn{5}{|l|}{ Acompanying taxa } \\
\hline Stipa tenacissima & + & + & 1.1 & . \\
\hline Capparis spinosa & + & 2.1 & . & . \\
\hline Launea acanthoclada & . & . & 1.1 & . \\
\hline Silene rouyana & . & . & . & + \\
\hline Stipa parviflora & . & . & . & + \\
\hline Pimpinella villosa & . & . & . & + \\
\hline Avenula bromoides & . & . & + & + \\
\hline
\end{tabular}

Syntaxonomic synopsis, following FenNANE (2003), and hierarchical relationships of the syntaxa cited in the text: Although many of the following associations are not mentioned in the text, all the syntaxa described in the study area for each phytosociological alliance have been included.
Class Asplenietea trichomanis (Braun-Blanquet in Meier \& Braun-Blanquet 1934) Oberdorfer 1977

Potentilletalia caulescentis Braun-Blanquet in Braun-Blanquet \& Jenny 1926

Potentillion caulescentis Braun-Blanquet in Braun-Blanquet \& Jenny 1926

Poo alpinae-Saxifragetum numidicae Romo 2008

Violion saxifragae Quézel 1952

Anthyllidetum warnieri sensu Quézel 1952

Arabido alpinae-Festucetum atlanticae Romo 2008

Arenarietum dyris Quézel 1952

Arenarietum mairei Quézel 1952

Campanulo embergeri-Erodietum atlanticae Quézel 1957

Drabetum mariae-aliciae (Quézel 1952) Deil \& Galán de Mera 1996

Drabetum oreadae (Maire 1924) Quézel 1957

Drabo hispanicae-Pterocephaletum kunkeliani

Romo 2008

Erigeronto celerieri-Valerianetum

globulariifolii Quézel 1957

Gnaphalietum genevoisii Quézel 1952

Pitardietum coerulescentis Quézel 1957

Saxifragetum gausseni Quézel 1952

Saxifragetum maireanae-Phagnaletum platyphyllae Quézel 1957

Saxifragetum mesatlantici Quézel 1957

Saxifrago globuliferae-Seslerietum argenteae Romo 2008

Saxifrago tricrenatae-Poetum ligulatae Romo 2008

Sileno dyris-Silenetum boryi Quézel 1957

Coeno-Sarcocapnetalia Deil \& Galán de Mera 1996

Rupicapnion africanae Daumas, Quézel \& Santa 1952

Rupicapnetum africanae Braun-Blanquet \& Maire 1924

Rupicapnetum mairei Braun-Blanquet \& Maire 1924

Rupicapnetum oranensis (Daumas, Quézel \& Santa 1952) Deil \& Galán de Mera 1996

Coeno-Sarcocapnion Deil \& Galán de Mera 1996

Sarcocapnetum enneaphyllae Rivas Goday 1941 Sarcocapnetum (crassifoliae) speciosae Esteve 
Table 8. Poo alpinae-Saxifragetum numidicae. Origin of the relevés: 1-7 Algeria, Djurjura massif, Jbel Heidzer, near Tala Guilef, between Yikjda and Tali Guilef, $36^{\circ} 39^{\prime} \mathrm{N} 4^{\circ} 05^{\prime}$ E.

\begin{tabular}{|c|c|c|c|c|c|c|c|}
\hline & \multicolumn{7}{|c|}{ Number of relevé } \\
\hline & 1 & 2 & 3 & 4 & 5 & 6 & 7 \\
\hline Aspect & $\mathrm{N}$ & $\mathrm{N}$ & $\mathrm{N}$ & $\mathrm{N}$ & $\mathrm{N}$ & $\mathrm{N}$ & $\mathrm{N}$ \\
\hline Slope & 90 & 90 & 90 & 90 & 85 & 90 & 80 \\
\hline Cover & 20 & 25 & 20 & 20 & 25 & 25 & 20 \\
\hline Altitude (x10) & 133 & 135 & 135 & 140 & 140 & 143 & 140 \\
\hline Studied surface $\left(\mathrm{m}^{2}\right)$ & 20 & 15 & 10 & 15 & 25 & 20 & 20 \\
\hline \multicolumn{8}{|c|}{ Characteristics of the association and of the superior units } \\
\hline Saxifraga numidica & 1.1 & + & . & + & 1.1 & 1.1 & + \\
\hline Leontodon djurjurae & + & + & . & 1.1 & + & 1.1 & 1.1 \\
\hline Arabis alpina subsp. doumetii & 1.1 & + & . & 2.2 & + & 1.1 & 1.2 \\
\hline Anthemis punctata & + & 1.1 & 1.1 & + & 1.1 & 1.1 & + \\
\hline Ceterach officinarum & + & +.1 & . & . & + & . & + \\
\hline Poa alpina subsp. numidica & . & . & 1.1 & + & 1.1 & 1.1 & + \\
\hline Hornungia petraea & . & . & . & + & . & . & . \\
\hline Sedum album & . & . & . & + & . & . & . \\
\hline \multicolumn{8}{|l|}{ Acompanying taxa } \\
\hline Arenaria leptoclados & . & . & . & + & . & . & + \\
\hline Bromus mollis & . & . & . & + & . & . & . \\
\hline Berberis hispanica & . & $\cdot$ & . & + & + & . & . \\
\hline Cotoneaster racemiflora & . & . & . & . & + & + & . \\
\hline Erysimum grandiflorum & $\cdot$ & . & . & + & . & . & . \\
\hline Valeriana tuberosa & . & . & + & . & . & . & . \\
\hline
\end{tabular}

\& Fernández-Casas 1971

Sarcocapno crassifoliae-Erodietum tordylioidis Daumas, Quézel \& Santa 1952

Sarcocapnetum atlanticae Quézel 1952

Saxifrago globuliferae-Geranietum cataractari Romo 2008

Anarrhino fruticosi-Astragetalia armati Quézel \& al. 1992

Bupleuro aiouensis-Globularion nainii Quézel
\& al. 1992

Centaureo benoistii-Galietum ephedroides Romo 2008

\section{ACKNOWLEDGEMENTS}

I thank Prof. Ulrich Deil (University of Freiburg) who made helpful comments on the manuscript. Also I would like to thank Prof. Walter Welss (University Erlangen-Nürnberg) who has enriched the work with 
his valuable suggestions. Samuel Pyke has improved the English language. This work has been completed in the year of death of Prof. Dr Oriol de Bolòs, Josias Braun Blanquet's disciple, to whom we owe so much, being our mentor.

\section{REFERENCES}

Barbero, M., P. QuÉzel \& S. Rivas-Martínez (1981). Contribution à l'étude des groupements forestiers et préforestiers du Maroc. Phytocoenologia 9 (3): 311-412.

Benabid, A. (1982). Brief aperçu sur la zonation altitudinale de la végétation climacique du Maroc. Ecologia Mediterranea 8 (1/2): 301-315.

Braun-Blanquet, J. (1977). Fitosociología. Editorial Blume, Madrid. 820 pp.

DeIL, U. (1994). Felsgesellschaften beiderseits der Strasse von Gibraltar. Hoppea 55: 757-814.

Deil, U. (1996). Zur Kenntnis der AdianteteaGesellschaften des Mittelmeerraumes und angrezender Gebiete. Phytocoenologia 26 (4): 481-536.

DEIL, U. (2006). Distribution, ecology and phytosociology of the N Moroccan endemic Ptilostemon leptophyllus (Compositae). Willdenowia 36: 409-412.

Deil, U. \& M. Hammoumi (1994). Contribution à l'étude des groupements rupicoles des Bokkoya (Littoral du Rif Central, Maroc). Acta Botanica Malacitana 22: 131-146.

DeIL, U. \& A. GALÁn DE Mera (1996). Contribution à la connaissance de la phytosociologie et la biogéographie des groupements rupicoles calcaires du Maroc. Bull. Inst. Sci. Rabat 20: 87-111.

DierschKe, H. (1994). Pflanzensoziologie. Grundlagen und Methoden. Ulmer Verlag, Stuttgart. 684 pp.

Fennane, M. (2003). Inventaire des communautés végétales à l'aide du phytosociologie, au Maroc. Ecologia Mediterranea 29: 87-106.

Fennane, M., M. Ibn Tattou, J. Mathez, A. Ouyahya \& J. El OuAlidi (1999). Flore pratique du Maroc, Vol. 1. Travaux de l'Institut Scientifique. Série Botanique 36, Éditions Okad, Rabat. 558 pp.

Fennane, M., M. Ibn Tattou, A. Ouyahya \& J. El OuAlidi (2007). Flore pratique du Maroc, Vol. 2. Travaux de l'Institut Scientifique. Série Botanique 38. Éditions Okad, Rabat. 636 pp.

Font Quer, P. (1931). De Flora Occidentale adnotationes. Cavanillesia 4: 88-90.

GÉHU, J. M. \& E. Biondi (1998). Nature et limites de quelques végétations littorales de type Macaronésien sur les côtes Sud occidentales du Maroc. Acta Botanica Barcinonensia 45: 439-453.

GonZÁlez Bueno, A. (1988). Les campanyes botàniques de Pius Font i Quer al Nord d'Africa. Treballs de
l'Institut Botànic de Barcelona 12. 174 pp.

Guittonneau, G. G. (1975). Contribution à l'étude caryosystématique et phylogénétique des Géraniacées dans le bassin méditerranéen. Colloq. Int. C.N.R.S 235: 195-205.

JAHANDIEZ, E. \& R. MAIRE (1931-1932). Catalogue des Plantes du Maroc, 3 vols. Imprimerie Minerva, Alger. 914 pp.

Mateos, M. A. (2003). Estudio florístico del Rif Occidental calizo, N de Marruecos. Universidad de Sevilla. Tesis doctoral. 645 pp.

Mateos, M. A. \& B. VAldés (2006). A new species of Globularia (Globulariaceae) from the Talassemtane National Park. N Morocco. Willdenowia 36: 409-412.

MÉDAIL, F. \& P. QuÉzEL (1999). The phytogeographical significance of S. W. Morocco compared to the Canary Islands. Plant Ecology 140: 221-244.

Mueller-Dumbois, D. \& H. Ellenberg (1974). Aims and methods of Vegetation Ecology. John Wiley \& sons, New York, London, Sidney and Toronto. 531 pp.

QuÉZEL, P. (1952). Contribution à l'étude phytogéographique et phytosociologique du Gran Atlas calcaire. Mém. Soc. Sci. Nat. Maroc 50: 1-57.

QuÉZEL, P. (1957). Le peuplement végétal des hautes montagnes de l'Afrique du Nord. Éditions P. Lechevalier, Paris. 464 pp.

QuÉzel, P. (2000). Réflexions sur l'évolution de la flore et de la végétation au Maghreb méditerranéen. Ibis Press, Paris. 118 pp.

Quézel, P. \& M. BARBERo (1981). Contribution à l'étude des formations présteppiques à genévriers au Maroc. Boletim Sociedade Broteriana, Serie 2, 53(2): 1137-1160.

Quézel, P., M. Barbero, A. Benabid \& S. RivasMARTínEZ (1994). Le passage de la végétation méditerranéenne à la végétation saharienne sur le revers méridional du Haut Atlas oriental (Maroc). Phytocoenologia 22 (4): 537-582.

QuÉzel, P. \& S. SANTA (1962-1963). Nouvelle flore de l'Algérie, 2 vol. CNRS, Paris. 1170 pp.

Romero-Zarco, C. (2002). Sesleria Scop. In: Valdés, B., M. Redjali, A. Achhal, S. L. Jury \& J. M. Montserrat (Eds.), Catalogue des plantes vasculaires du Nord de Maroc, Incluant des clés d'identification, vol. 2. CSIC. Madrid: 787.

Romo, A. M. (1987). De Sesleris Ibericis Maroccanis Notulae Quaedam. Fontqueria 14: 11-13.

Romo, A. M. (1995). Les muntanyes del Rif. El manteniment de la biodiversitat en muntanyes densament poblades. Congrès internacional de les altes Muntanyes de la Mediterrània. Mountain Wilderness de Catalunya: 105-115. Barcelona.

Romo, A. M. (2003). Potentilla L. In: Valdés, B., M. Redjali, A. Achhal, S. L. Jury \& J. M. Montserrat 
(Eds.), Catalogue des plantes vasculaires du Nord de Maroc, Incluant des clés d'identification, vol 1. CSIC. Madrid: 291-293.

Romo, A. M. \& A. BorATYŃSKI (2005). Chorology of Juniperus thurifera (Cupressaceae) in Morocco. Dendrobiology 54: 41-50.

Romo, A. M. \& A. BorATYŃSKI (2007a). Nomenclatural note on Juniperus thurifera subsp. africana (Cupressaceae). Annales Botanici Fennici 44 (1): 1-7.

Romo, A. M. \& A. BorATYŃSKi (2007b). Notes and contributions to the vascular flora of Oukaïmeden (Central High Atlas, Morocco). Candollea 62: 69-89.

Romo, A. M., S. Cirujano, J. B. Peris \& G. Stubing (1999). The genus Pterocephalus (Dipsacaceae) in Morocco. Feddes Repertorium 110: 13-17.
SÁez, L., J. M. Montserrat \& J. A. Rosselló (2002). A new subspecies of Arenaria grandiflora (Caryophyllaceae) from the Rif Mountains (Northern Morocco). Folia Geobotanica 37: 339-349.

Wojterski, T. W. (1985). Guide de l'excursion internationale de Phytosociologie. Algérie du Nord. Institut National Agronomique, El Harrach. 274 pp. Valdés, B., M. Redjali, A. AchHal, S. L. JuRy \& J. M. Montserrat (2002). Catalogue des plantes vasculaires du Nord de Maroc, Incluant des clés d'identification, vol. 2 CSIC, Madrid. 1007 pp.

Vargas, P. (2003). Saxifraga L. In: Valdés, B., M. Redjali, A. Achhal, S. L. Jury \& J. M. Montserrat (Eds.), Catalogue des plantes vasculaires du Nord de Maroc, Incluant des clés d'identification. CSIC, Madrid: 282-284. 